HARVARD UNIVERSITY.

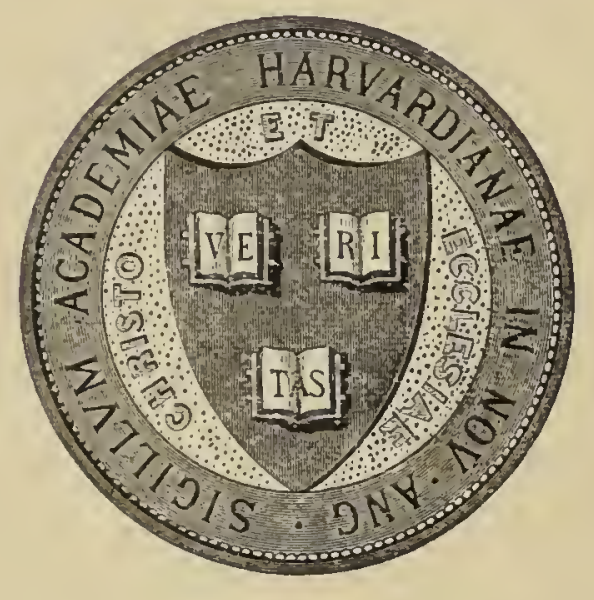

LIBRARY

OF THE

MUSEUM OF COMPARATIVE ZOÖLOGY • $5 \underline{8}, 527$

BEQUEST OF

WALTER FAXON

fanuary 21,1922 
THE

\title{
ATLANTIC MONTHLY
}

DEVOTED TO

\author{
Literature, Science, Art, and Politics \\ VOLUME XLIX.-NUMBER 293
}

MARCH, I 882

\section{CONTENTS}

The Story of the Hoosac Tunnel. $N . H$.

Egleston . . . . . . . . . 289

LoKr. Elizabeth Robins . . . . . . . 304

The House of a Merchant Prince. III.-V.

William H. Bishop . . . . . . . . . 3r4

Love AND DEath. Charlotte Fiske Bates. . 329

Hurricanes. N. S. Shaler. . . . . 330 Hyms and Hymn-Tinkers. A. P. Hitcheock 336 Av Ecio of Passion. VI.-VIII. George

Parsons Lathrop . . . . . . . . . 346 SYRINX. Edith M. Thomas . . . . . . . 36I LifE AND THE DREAM OF LIFE. Fohn Trone-

bridge. . . . . . . . . . . . $3^{62}$ A Visit to Jerusalem. Edward E. Hale $\cdot 368$ AT LAST. Fohn Greesleaf Whitticr . . . 374 Among the Sky Lines. H. H. • • . . 37.5 OUR Winter Birds. Mary Treat . . . 381 BEFORE THE CURFEW. I829-1882. Oliver

Wendell Holmes . . . . . . . . 386 A Difeiculty in Hamlet. $\mathcal{F} \cdot P$. Quincy $\cdot 3^{88}$ The Political Situation. . . . . 393
On a Great Man whose Mind is Cloud. ING. Edmund C. Stedman . . . . . . 399 Captarn Farquhar. H. A. Huntington . 399 Campaigns of the Civil War. S. M. Quincy 407

Vol. I. The Outbreak of Rebellion. By John G. Nicolay. Vol. II. From Fort Henry to Corinth. By M. IF. Force. Vol. III. The Peninsula. MicClellan's Campaign of 1862 . By Alexander S. Webb.

COBDEN . . . . . . . . . . . . 4I5

The Light Literature of Travel . . . 419

House's Japanese Episodes. - Hassard's A Pickwickian Pilgrimage. - Miss Sarah Orne Jewett's Country By-Ways.

Mr. Warner's Brographical Studies . $\quad 422$ Warner's Captain John Smith (1579-1631), sometine Governor of Virginia and Admiral of New England. - Warner's Washington Irving.

The Contributors' Club . . . . . . 424

Prefaces. - A Color-Cure. - Provincial Dullness. - A Chapter on Deformity. - A Contributor's View of Wordsworth's Ode on the Intimations of Immortality.

Books of the Month . . . . . 430

BOSTON

\section{HOUGHTON, MIFFLIN AND COMPANY}

\author{
NEW YORK: II EAST SEVENTEENTH STREET
}

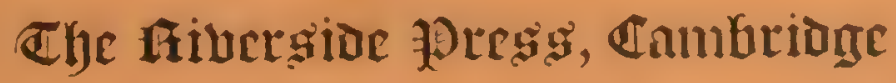

Entered at the Post Omco at Boston as second-class matter 


\section{NEW BOOKS.}

\section{BRET HARTE'S WORKS, New, Complete Edition.}

This edition will consist of five volumes, erown octavo, printed from entirely new plates with attractive type, on paper of ehoice quality, and bound in the best and most tasteful style of the Riverside Press.

\section{NOW READY:}

Vol. I. PUETICAL WORTS (including, with many new poems, the volumes originally published under the titles of "Poems," "East and West Poems," and "Echoes of the Foot Hills") and the dramatic pice $\operatorname{IVO} M \boldsymbol{M} N$ OF $S A N D Y$ BAR, with an Introduetion by the author, and a fine Steel Portrait. \$2.00.

\section{JAMES ABRAM GARFIELD.}

The admirable Eulogy delivered at Worcester, Mass., in ${ }^{\star}$ December, by Hon. GEorge F.

Hoar. With a fine Steel Portrait.

\section{MAGYAR LAND.}

BEING THE NARRATIVE OF OUR TRAVELS THROUGH THE HIGHLANDS AND LOWLANDS OF HUNGARY. By a Fellow of the Carpathian Society. 2 rols. 8 ro. With Illustrations. $\$ 10.00$.

A highly interesting story of travel through a country and among people comparatively little known by Americans.

\section{ASPECTS OF POETRY.}

BEING LECTURES DELIVERED AT OXFORD. By John Campbell SHairp,

LL. D., Professor of Poetry, Oxford ; author of "Culture and Religion," "Poetic Interpretation of Nature," and "Studies in Poetry and Philosophy." 1 rol. 16mo, gilt top. \$1.50.

Contents: The Province of Poetry; Criticism and Creation; The Spiritual Side of Poetry; The Poet a Rerealer; Poetic Style in Moderu English Poetry; Virgil as a Religious Poet: Scottish Song, and Burns Shelley as a Lyric Poet; The Poetry of the Scottish Highlands - Ossian; Modern Gaelic Bards - Dunean MacIntyre; The 'Three Yarrows; The White Doe of Rylstone; The Homeric Spirit in Walter Scott; Prose Poets; Thomas Carlyle; Cardinal Newman.

Those who have read Principal Shairp's previous books will gladly welcome this. His treatment of the subjeet is so fresh and so scholarly that the book is one of remarkable interest to all lovers of poetry and of literature.

\section{HAWTHORNE INDEX.}

AN ANALYTICAL INDEX TO THE WORKS OF NATHANIEL HAW'THORNE, with a Sketch of his Life. Uniform with the "Little Classic" Edition of Hawthorne's Works. $\$ 1.25$. Also uniform with the Library Edition. $\$ 2.00$.

This full Index enables one to refer immediately to any eharaeter, scene, ineident, or striking passage in Hawthorne's writings, and eannot fail to be very aceeptablo to all his readers.

\section{THE MIND OF MENCIUS:}

OR POLITICAL ECONOMY FOUNDED UPON MORAL PHILOSOPHY. A Systematic Digest of the Doctrines of the Chinese Philosopher Meneius. Classified and Translated, with Comments and Explanations, by Rev. Ernst Faber. Translated from the German, with additional Notes, by Rev. A. B. Hotchinson, C. M. S., Chureh Mission, Hong Kong. Vol. 26 in the Philosophical Library. 8vo, gilt top. 3.50 .

A systematic statement of the ideas of Mencius, who holds so commanding a position in the intellectual history of China; inraluable to the student of moral philosophy, political economy, Chinese bistory, and to missionaries.

*** For sale by Booksellers. Sent, post-paid, on receipt of price by the Publishers,

HOUGHTON, MIFFLIN AND COMPANY, Boston, Mass. 
like wine held up to light. When the pod bursts, and the silver-winged seed first is set partly free, it instantly coils and twists around the stem, as if loath to depart. The lower lialf of the plant thus becomes tangled and draped witl this fine curling silver plumage, rising above which stauds the superb columnar red stem set with the narrow red pods. There are many wild clearings where this fire-weed grows solid by the acre; and on a breezy day in September every wind that sweeps across suatches whole fields of these silver plumes, and whirls them aloft, to separate and float, and drift as they may.

We saw on this day, in many a sky "offung," fleets of them, which had almost a preternatural look, as of shoals of glittering pearl flies, or slow-floating snow, where no snow could be. At sunset, great masses of crimson and gold clouds hovered above the heights where we had been in the morning. Long after these had all faded into gray, there lingered at the highest peak, as if clinging to it, one long narrow thread of crimson. It seemed to float like a banner; and, recalling the weird valley and the weird water's, lying high, dark, and lonely at the foot of this peak, and the tone of voice in which the doctor's wife had asked, "What more could I want?" it seemed natural enough that a cloud should linger and float there, unseen and unknown of the strange recluses, but keeping "colors flying" for them till dark.

\section{H. H.}

\section{OUR WINTER BIRDS.}

AFter several years' careful obser-. vation in Southern New Jersey, I find that winter gives us a phase in the life and character of birds quite unlike that displayed in summer by the same species, yet none the less interesting.

The permanent residents of this latitude which come about our house and grounds are the song sparrow, field sparrow, English sparrow, yellow-bird, pine linnet, bluebird, robin, meadow lark, quail, bluejay, crow, and several species of hawlss and owls. 'The Northern birds which make this section their winter home are the white-throated sparrow, fox sparrow, tree sparrow, chickadee, and the dark slate-colored sparrow, or snow-bird, as it is more usually called. There are also several species restricted to the woods, with which I am unfamiliar.

Most of these birds will become quite tame with a little care on our part, and will soon come to look to us for their daily food. Especially if the ground is covered with snow, they will learn to become clamorous for their food, even alighting on the window-sills and striking the glass, apparently to attract attention to their wants. In summer the same species are much more shy, so winter gives us a better opportunity to study the habits and dispositions of the various birds which remain with us.

With most species family ties are not broken in winter. Bluebirds, perhaps more so than most of our birds, maintain a strict family relation during the winter, - even while assembling in large flocks. Not only do the partner's remain true to each other during their lives, but they continue their care over the young throughout the first fall and winter.

When a pair of blnebirds succeed in rearing three broods in a season, in the autumn these broods unite and stay with the parents, making a little flock of 
about fourteen. All the autumn through they keep together, feeding from the same bushes, poke, ampelopsis, and other wild berries, and upon such stray insects as they may find.

The first cold days of December send them to the cedar swamps, where great numbers congregate. Here, too, large flocks of robins keep them company. But each mild day brings the bluebirds from their retreat back to their unforgotten home. And there is nothing more fascinating in bird life than to see the frolics of the young birds and the grave demeanor of the parents. The young visit the various houses in which they were reared, sometimes two or three entering at the same time, and all the while keeping up their low sweet twittering, as if conversing.

But in the spring all is changed. The parents tell the young in a very peremptory manner that they must now seek new homes. Sometimes the young are quite persistent abont reinaining, when the parents at last seem to become exasperiated, and drive them fiercely from the premises.

During the summer of 1880 , I was particularly interested in a pair of bluebirds which had the misfortune to rear but one brood of three during the season. The young were hatched in a little house fastened to the railing of an upper piazza. They became quite tame, and remained with us until the first week in December. After this I saw them no more until the first day of January, 1881, when, to my surprise, the entire family came to my study window, - a bay window, fronting south, - and perched upon the sill. The mercury stood fifteen degrees below zero on this morning, an unusual temperature for our latitude.

I have found that an intensely cold day will drive both robins and bluebirds from their retreat in the cedars to our homes, as if they hoped for better protection against the cold.
Our little family had accompanied a sorry-looking flock of forty or fifty bluebirds, with ruffled feathers, which had lalted in the vineyard near the loouse on this bitter morning.

By ten o'clock the sun shone brightly against the window glass, and the warm fire within helped to make the windowsill comfortable; and here all five of the birds perched, thus getting the full force of the sun's rays. After basking awhile in the sun, their feathers smoothed down, and they seemed quite bright and happy, and toward noon disappeared with the flock. Several times, on the coldest days, during this severe winter, this little family came to my window in the same manner.

I could mention several other instances which have come under my observation, in proof that the parent bluebirds, with their broods of the previous season, are a united family; but one more will suffice.

The past summer, 1851, a pair of bluebirds occupied a box placed on a projecting part of the cornice, in the rear of the house. After the first brood left the box, the parents soon commenced to tear out the old nest, preparatory for a second family in the same box. The second nest is usually built in some other place, in the vicinity of the first, and here was no lack of empty boxes for them to choose from; but for some reason, known only to themselves, they were determined to occupy the house of their first choice, notwithstanding the bad condition in which it was left.

Seeing their determination, we had the box emptied of its contents, and, as might be expected, found it swarming with vermin. We sprinkled it thoroughly with insect powder, and the birds commenced at once to build.

When the second brood were hatched the English sparrows annoyed the parent bluebirds exceedingly by going to the box and looking in, and one of the spar rows even liad the audacity to attempt 
to alopt and feed the young bluebirds. What could the parents do? They could not stay and watch the sparrows continuously, for thic lusty young were clamorous for food. So these wise birds called togrether the elder brood, - eliter brothers and sisters, whom I had not seen for weeks, - who were by this time as large as the parents, but readily distinguished from them by thcir curiously mottled breasts, which they wear the first summer. 'The parcnts instructed these young ones to keep guard over the housc while they were away in scarch of food, which they did for several days. The house was scarcely left a moment. One or more of the family were almost constantly present, and would dart at the sparrows whenever they made an attempt to come near, until the young left the box; and now, at this present writing, - October, - this happy family are united; both broods, with the parents, eating poke-berries from a large bush which I have allowed to remain expressly for them.

When the ground is covered witl sllor, the various species of our native sparrows, so full of life and jollity, will doubly repay any lover of birds for the care bestorved upon them.

Last winter I kept a space of ground beneath my study window frec from snow, where I scattered coarse Indian meal and millet sced, and this ground soon becime a mimic stage for these bright actors. The names of the most noted were Junco hyemulis, Zonotrichice albicollis, Spizella monticola, and Melospiza melodia. The names of these actors are known throughout the civilized world. All nations recognize the family name, and often the specific namc gives a clew to the character; as hyemalis, our winter or snow bird; monticola, a dweller in the mountains, where this species spends its summers and rears its young; melodia, the swcet songstcr, or song sparrow.

Junco hyemalis is excellent in dra- matic performance. 'Two of these actors meet face to face on the stage, in their dark glossy coats, and each tries to make the other quail before his fixed gaze. Nearcr and nearer they cone, constantly chattering and bowing, until within a few inches of each othcr, when they elevate their heads and bodies to a perfectly upright position, and chatter vcliemently with wide open mouths. Sometimes onc of the actors leaves the stage at this juncture, and the other remains; but gcnerally they both withdraw and have a trial of strength in the air.

And now Zonotrichia albicollis comes forward in another act. IIe is the most gorgeously attired and the largest actor in the drama. The crown of his head is black, bordered with white, and his full muffled throat is pure white, sharply contrasting with the dark ash of lis breast. The back of his coat is striped with black, chestnut, and fulvous white. He excels Junco in tragi-comic performance. He opens the act with a prolonged musical note, and flattens himsclf in front of a brother actor, and spreads his tail fan-shaped. Faster and faster come the notes from the two actors, until they are so blended that we can scarcely distinguish one from the other. The birds approach each other squatted to the ground. Their fect harc disappeared. When the climax is reached, like Junco, they love the stage in a twinkling.

Usually the actors are of the same species, but occasionally Junco and Zonotrichia enliven the drama,-each acting his part with his own individual characteristics. Junco chatters and bows to Zonotrichia, who cowers apparently at his feet, meanwhile cntertaining his audience with his long mnsical notes. And now, while Junco is straightened to his utmost hcight, hurling his rapid invectives, Zonotrichia leaps up like a flash, and strikes him in the brcast, with sufficient force to hurl him across the stage. 
But Junco is not always taken by surprise and kicked from the stage in this inglorious fashion. Although the smaller bird, he is occasionally victorious.

I would not have it understood that these small actors are entirely given to theatricals; there are times when they are quiet and orderly, and seem to be enjoying each other's society.

My favorite among them all is Spizella monticola. He comes to $11 \mathrm{~s}$ toward the end of October, and remains until April. The crown of his head is a bright chestnut, and upon his shoulders are chestnut epaulets; his breast is a soft ashy color with a dark blotch in the centre; the back of his coat is streaked with black, chestnut, and flaxen, and two conspicuous white cross-bars are on his wings. He is the handsomest member of the genus, and considerably larger than the little chipping sparrow (Spizella socialis), that is always about our door's in summer, but goes South to winter.

Although Spizella monticola flock together in considerable numbers, yet they keep the family relation as strictly as the bluebirds, generally in groups of four or six, which indicates that the parents rear but one brood in a season, or, if more, each brood keeps by itself. The birds comprising these groups do not quarrel, but are so closely attached that one cannot fly away without the others following. 'The actors in the quarrels and trials of strength are made up of birds from different groups, - strangers trying for the championship. This species does not go through with many preliminaries before the final act. They commence chattering, and clinch at once. Up, up, they go, ligh in the air, striking, railing at each other as they ascend, until one is victorious.

The English sparrow merits notice, although I must confess he is not a favorite with me. He is not so graceful or beautiful as our indigenous species; still I do not wish to be unjust toward him. I have uniformly found lim to be the least quarrelsome of any bird that comes about the grounds. I have never seen lim aggressive toward our own species, even when mixing thickly with them. He usually prefers to remain about the barn and stable, where an abundance of food is scattered for the fowls and pigeons, but occasionally quite a flock comes and mingles with our native species beneath my window, and here I can watch them at my leisure. Our indigenous birds know better than to attack him, for he is stronger and more heavily built than they are.

Only once since my observations commenced have I seen anything like a quarrel between the English sparrow and our native species, and in this instance the aggressor was the champion Junco, who was ruler over his own tribe, and had also whipped many whitethroats and song sparrows.

A little group of English sparrows was quietly feeding beneath the window. Junco struts around them, and chatters; but they pay no attention, not even deigning to look at him. Failing in his attempts to elicit any notice, he flits to the window-sill, and looks down upon them. Finally he seems to single out one which has wandered a little apart from the rest, and in a twinkling he strikes him broadside, throwing him off his feet, and then flies several yards away. The English sparrow is on his feet in an instant, slowly turning his head all around in evident amazement, but is soon eating again. Junco does not renew the attack, but mingles with his kind, picking up seeds. The English sparrow, however, has his eye upon him, and now Junco has to keep at a safe distance.

The summer yellow-bird also mixes freely with the various sparrows. This charming little creature looks so different in his plain gray winter cont, which he puts on in September and wears 
until April, that it is with difficulty we recognize him, so complete is the transformation. 'The brilliant yellow and black have disappeared, and only faint tracings of greenish-yellow about the head and throat remain. But he is apparently as happy in his sombre suit, picking up millet, as when more brilliantly attired, and rollicking amid the rounded globes of the dindelion, scattering the airy seeds, and capturing them as they start on their winged course.

Our little gymnast, the titmouse, or black-capped chickadee, must not be forgotten. He is not regarded as migratory, and yet he comes to us each winter, and seems to go northward in the spring. He is the most fearless bird of my acquaintance, frequently eating from my hand, and is almost omnivorous, taking anything that comes in his way, from a bone that we hang on a tree for his tiny lordship to pick, down to a plate of preserved berries which we have placed on the doorstep for the bluebirds. But he is quite exclusive in his society, and does not mingle freely with the other winter birds. 'The cold Northern snow-storms seem only to increase his jollity; now here, now there, clinging to a bough, head downward, chanting his chick-a-dee-dee. Emersou pictures him to the life in the following lines :-

\footnotetext{
"When piped a tiny voice hard by, Gay and polite, a cheerful cry, Chic-chicadeedee! sancy note Out of sound heart and merry throat, As if it said, Good-day, good sir! Fine afternoon, old passenger! Happy to meet you in these places, Where January brings few faees. This poet, though he live apart, Mored by his hospitalle heart, Sped, when I passed his sylran fort, To do the honors of his court, As fits a feathered lord of land; Flew near, with soft wing grazed $m v$ hand, VOL. XLIX. - NO. 293.

Hopped on the bough, then, darting low, Prints his small impress in the snow,

Shows feats of his gymuastic play,

Head dowraward, clinging to the spray."

When the smaller birds have been driven from the fields and woodlands to our dwellings by the snow, the birds of prey are forced to follow them; so there is scarcely a day but we see various species of hawk or the day owl (Surnia Hudsonica) watching their opportunity for a meal. We vaiuly try to frighten them away; but lunger knows no law, and they are often successful in snatching a bird within a few feet of us.

This owl, S. Hudsonica, is less timid and much more persistent than the hawk in following his prey. Often, when I think I have frightened him from the neighborhood, he will noiselessly slip out of an evergreen, and with the coolest audacity take a sparrow in my near vicinity.

Sometimes one drops down from the roof of the house, among the feeding birds beneatl my window, and, taking one of these beautiful creatures in his claws, proceeds to the nearest post, and crushes its life out. It is a mercy to my little favorite to let the owl alone after he has secured his prey, for he kills it much more quickly than when disturbed.

At sight of this apparent cruelty in nature comes the impulse to shoot these raptorial birds. But when we think of that other biped, whom it is not lawful to shoot, who often hunts and kills the beautiful denizens of our fields and woodlands, from mere wantonness and sport of the cliase, the hawk, or owl, which takes a bird only to appease his lunger, towers above him in moral rectitude. So our gun leans idly against the wall.

Mary Treat. 


\section{BEFORE THE CURFEW.}

1829-1882.

Noт bed-time yet! The night-winds blow, The stars are out, - full well we know

The nurse is on the stair,

With hand of ice and cheek of snow,

And frozen lips that whisper low,

"Come, children, it is time to go

My peaceful couch to share."

No years a wakeful heart can tire;

Not bed-time yet! Come, stir the fire

And warm your dear old hands;

Kind mother earth we love so well

Has pleasant stories yet to tell

Before we hear the curfew bell;

Still glow the burning brands.

Not bed-time yet! We long to know

What wouders time has yet to show,

What unborn years shall bring;

What ship the Arctic pole shall reach,

What lessons Science waits to teach,

What sermons there are left to preach,

What poems yet to sing.

What next? we ask; and is it true The sunshine falls on notling new,

As Israel's king declared?

Was ocean ploughed with harnessed fire?

Were nations coupled with a wire?

Did Tarshish telegraph to Tyre?

How Hiram would have stared!

And what if Sheba's curious queen,

Who came to see, - and to be seen, -

Or something new to seek,

And swooned, as ladies sometimes do,

At sights that thrilled her through and through,

Had heard, as she was coming to,

A locomotive's shriek,

And seen a rushing railway train

As she looked out along the plain

From David's lofty tower, -

A mile of smoke thrat blots the sky 


\section{THE GREAT BIBLE DICTIONARY.}

\section{BY WILLIAM SMITH.}

Unabridged, enlarged, and corrected. Edited by II. B. IIAckreT, D. D., and Prof. Ezra Aввот. 4 volumes, 3,667 pages, with 596 illustrations. Price, in cloth, $\$ 20.00$; slieep, $\$ 25.00$; lialf morocco, $\$ 30.00$; half russia, $\$ 35.00$; full morocco, $\$ 40.00$; full russia, $\$ 45.00$.

There are several American editions of Smith's Dictionary of the Bible, but this is the only edition which comprises the contents of the original English edition, unabridged, with very considerable and important alditions by Professors Hackett and Abbot, and twenty-six other eminent $\Lambda$ merican scholars.

No similar work in our own or in any other language is for a moment to be comparod with it. Quarterly Review (London).

'There cannot be two opinions about the merits of Smith's Bible Dietionary. What was, to begin with, the best book of its kind in our language, is now still better." - Prof. Koswell D. Hitchcock.

In paper, presswork, cuts, maps, etc., we do not see anything to choose between this and the more costly English origrinal; while in a multitude of other respects which affect the trustworthiness, thoroughuess, and supreme excellence of the work as a thesaurus of Biblical knowledge, this is vastly to be preferred. - Congregational Review (Boston).

- No other edition of Smith's Bible Dictionary is nearly as full, complete, or accurate as this, tohich was edited by Prof. H. B. Hackett, D. D., and Prof. Ezra Abbot.

*** For sale by Booksellers. Sent, post-paid, on receipt of price by the Publishers,

HOUGHTON, MHFLIN AND COMPANY, Boston, Mass.

\section{JOSEPH COOK'S BOSTON MONDAY LECTURES.}

BIOLOGY.

TRANSCENDENTALISM.

ORTHODOXY. CONSCIENCE.
HEREDITY.

MARRIAGE.

LABOR.

SOCIALISM.

Eight volumes, with Preludes on Current Events. Each rolume, $12 \mathrm{mo}, \$ 1.50$.

BRITISH OPINIONS.

Fresh, vigorous, and outspoken, Mr. Cook's highly seasoned lectures on ORTHonoxy may be recommended as $a$ wholesome stimulant to readers whose jaded literary appctites require a tillip. Mr. Conk is a consummate master of the art of arousing and arresting the attention and interest of a popular asscmbly. He is never e:ther dall or prosy. It must be admitted that he has shown that evangelical theology, when stripped of the exarations of language, in which it has too frequently becn expressed, and of the crude and fanatical exaggerations of language, in which ille professors, and enunciated in well-considercd and definite terms, has really a good deal to say for itself. - The Scotsman (Edinburgh), October 17, 1878.

His lectures give evidencc of a thorongh grasp of his many-sided subject. His residence in Germany has happily emancipated lim fron the narrowness and insularity so characteristic of much linglish thonght." His acquaintance with general literature enables him to relieve the scverity of his arguncnt with many an apt acquaintance with gcneral whilst his strong, watchful interest in current political events and practical life quotation and illustration, whilst his strong, which adds greatle to thcir charm. It would be dificult to mention any writer on this side whose discussion., of these great questions will so well repay perusal. - Glasgow Herald.

Fnll of keen criticism, relentless logic, and withering sarcasm, the citadel as well as the outworks of scientific niateriatism is hero riddled through and through with burning shot. - Sword and Trowel (Mr. Spurgcon's), November, 1878.

** For sale by all Booksellers. Sent, post-paid, on receipt of price by the Publishers,

HOUGHTON, MIFFLIN AND COMPANY, Boston, Mass. 
ONE OF THE SOUNDEST LIFE COMPANIES IN THE WORLD.

LOW CASH RATES.

AMPLE SECURITY.

The Travelers

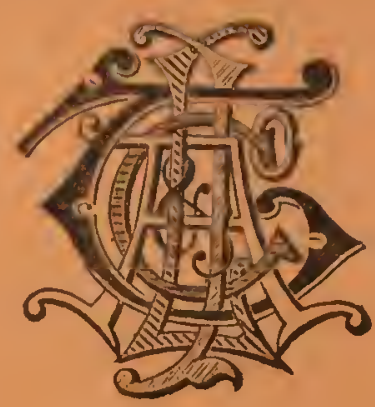

DEFINITE CONTRACT.

A CLEAN RECORD.

HARTFORD, CONN.

Does a Large and Increasing Business in Regular Life Insurance, AS WELL AS THE

LARGEST ACCIDENT BUSINESS IN THE WORLD.

Amount Life Insurance now in force, over $\$ 20,000,000$. GAINED NEARLY ONE AND A HALF MILLIONS IN 1881.

Has Paid to Life Policy-Holders over $\$ 1,900,000$.

Assets, $\$ 6,114,000$. Liabilities, $\$ 4,598,000$. Surplus, $\$ 1,516,000$.

JAMES G. BATTERSON, Pres't.

RODNEY DENNIS, Sec'y.

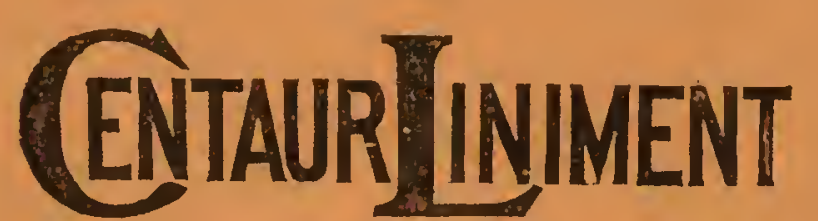

THE MOS T

Potent, Powerful, and Penetrating Pain-Reliever, ever devised by man.

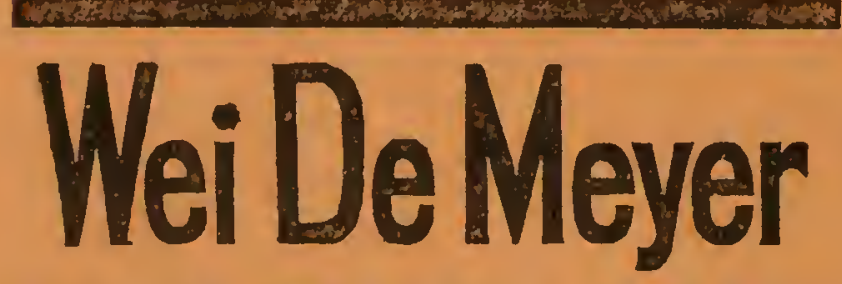

WEI DE MEYER'S CATARRH CURE. The only lrnown treatment which will roally curo Catarrh. "Treatise." with statements by the cured, mailed free, by D. B. Dowey \& Co., 46 Dey St., N. $\mathbf{X}$.

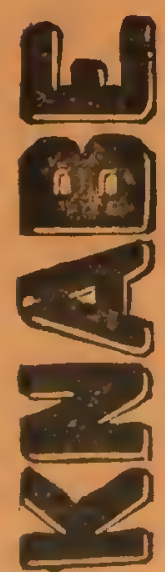

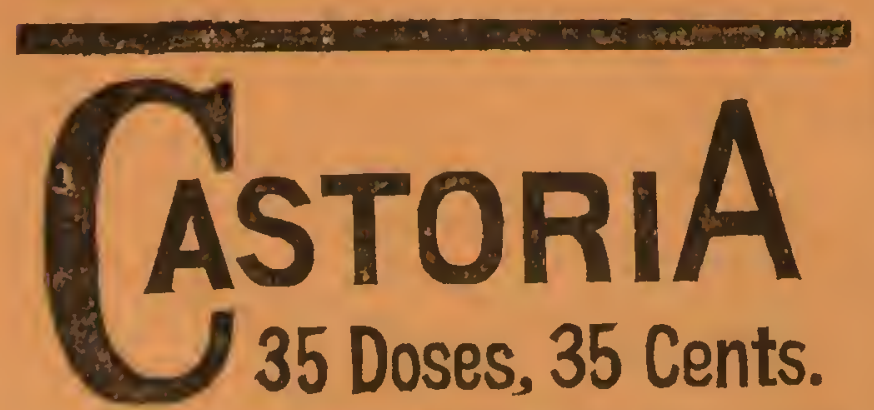

Castoria regalates the Bowels, cures Flatulency and Wind-Colic, and allnys Foverishness. Wonderful for Children. It is not Narootic.

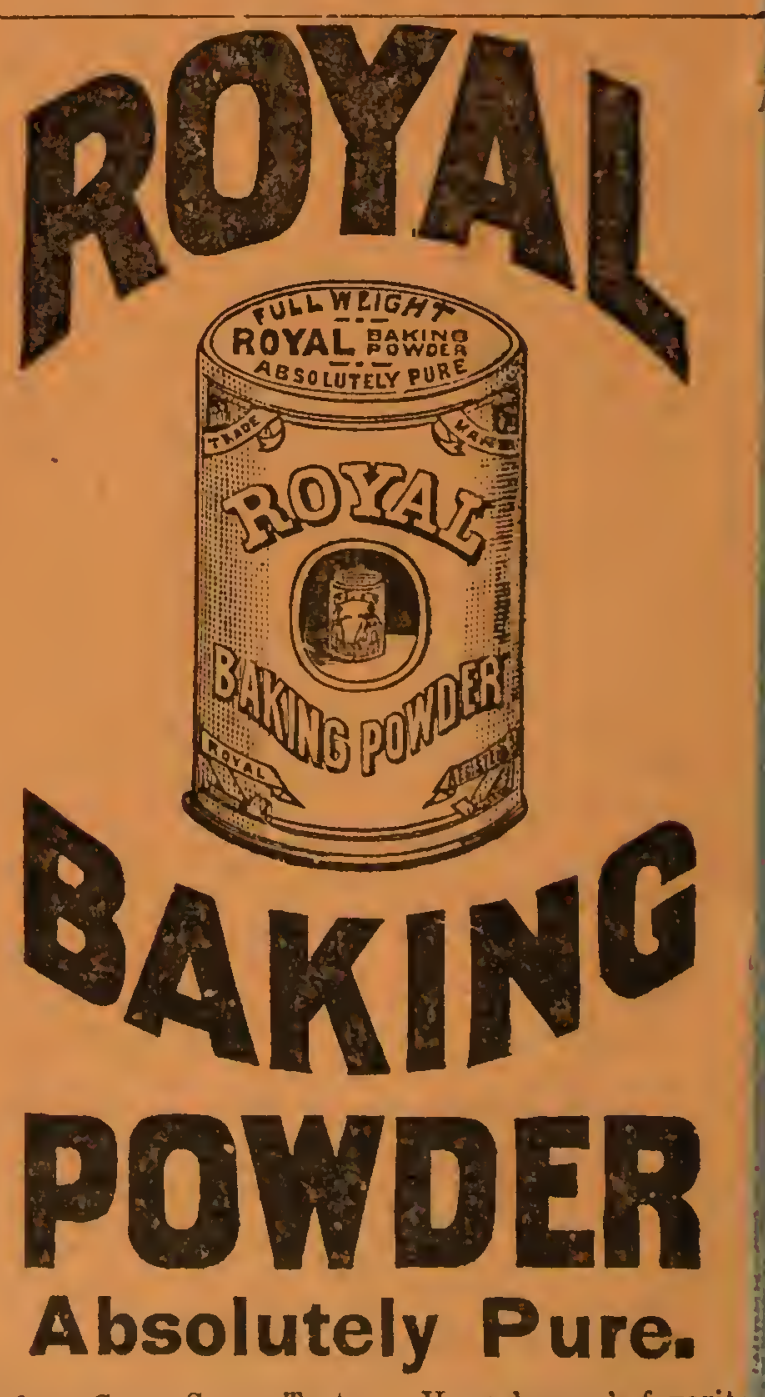

Made from Grape Cream Tartar. Ilousekeeper's favorite leading cities of the world. No other preparation ma such light, flaky hot breads or luxurious pastry. Can eaten by dyspeptics without fear of the ills resulting fr

heavy, indigestible food.
The rich cooking flavors, RoYAL TANILLA and LEar? surpass all others in aroma, taste, and strength. ROYAL BAKING POWDER CO., NEF YORE. 


\section{Gaylord Bros.
Makers
Syracuse, N. Y
PAT. JAN, 21, 1908 \\ Gaylord Bros
Makers
Syracuse, N. Y
PAT. JAN, 21, 1908 \\ Gaylord Bros
Makers
Syracuse, N. Y
PAT. JAN, 21, 1908}


